\title{
Improving Students' Independence and Collaboration with Blended Learning
}

\author{
Erly Wahyuni \\ University of Muhammadiyah Malang \\ erlywahyuni@ymail.com
}

\begin{abstract}
Now that web-based learning has emerged as a major trend in higher education. Many people have opportunities to develop and enhance independent or collaborative learning through a material which can be supported by technology and online learning. This study was aimed at 1) finding out how Blended Learning was implemented to improve students' independency and collaboration in listening class, 2) finding out how Blended Learning can improve students' independency and collaboration, 3) finding out students' response toward the implementation of Blended Learning in listening class. The subjects of this study are an English lecturer and the second semester students of English Dept. which consists of 28 students who are taking Listening Class. The research designs used are descriptive qualitative and quantitative research. The instruments of this study are observation, interview, and open-ended questionnaire with likert scale. The techniques of data analysis for quantitative research uses a simple percentage and qualitative research is with data reduction, data presentation, and conclusion: drawing or verifying. The result of the research showed that 1 ) the use of blended learning in teaching listening offered ways for lecturer to be more effective in the teaching and learning process, 2) blended learning was able to improve students' indepedency and collaboration in listening class, and 3) this study demonstrated the positive response for the students.
\end{abstract}

Keywords: independence, collaboration, and blended learning

\section{INTRODUCTION}

The development of information and communication technology has given effect in the world of education in Indonesia especially in the learning process. One of the indicators of this phenomenon is the shift in the learning process where the interaction between educators and learners not only done through face-to-face relationships but also with media communication like computer, internet, and so on [14].

Student's openness in accessing the internet can be utilized to support the learning process, to add knowledge and understanding of the subject matter they are studying. With free time which students have outside of school hours, they can use it to learn independently using ICT facilities. Teachers can support learning that students have done in school by using a web site that is accessible to students to study outside school. One of the alternative learning approaches is Blended Learning.

Blended learning is the combination of instruction from two historically separate models of teaching and learning: traditional face-to-face learning systems and distributed learning systems [6]. In addition, Blended learning approach can be used to conduct learning activities outside school with utilizing Information and Communication Technology without eliminating face-toface learning activities at school and encouraging students learning models to develop abilities of thinking [3]. Researches on blended learning about Effect of Blended Learning to Academic Achievement show that blended learning environment had generated a significant difference in students' academic achievement \{4). Besides, study about Blended learning effectiveness: the relationship between student characteristics, design features and outcomes indicates some of the students' characteristics/backgrounds and design features are significant predictors for student learning outcomes in blended learning $\{8\}$. Furthermore, $a$ research about the Effect of blended learning to the students' ahievement in Grammar Class explains that blended learning was effective to assist the students to learn English grammar [7].

Based on some previous studies above, it can be said that the main purpose of blended learning is to provide opportunities for the various characteristics of learners to become self-sustaining, sustainable, and develop throughout life, so that learning will be more effective, more efficient, and more interesting.

The purposes of the research are to describe how blended learning was applied in listening class, to identify the students' independence and collaboration and also to know the students' response on the use of blended approach in learning listening.

\section{METHOD}

The design of the research was mixed method. It is a research which combines quantitative and qualitative method in different ways to understanding of the phenomenon [1]. Since the purpose of the study was to know the students'response, the designed used was quantitative research. Meanwhile, the qualitative analysis was used to know the implementation of blended 
learning and to identify students' acitivty collaboratively and independently. The instruments of this study were observation, interview, and open-ended questionnaire with likert scale. The setting of the research is in English Department, University of Muhammadiyah Malang

The data was compiled from an English teacher/lecturer and third semester students of English department UMM with the total number of 28 students. They are considered as subjects of the research.

After the data were collected, they were then analyzed. Likert scale is used to gauge attitudes, values, and opinions. It functions by having students to complete a questionnaire that requires them to indicate the extent to which they agree or disagree with a series of statements. The technique of analyzing the data in this research was started with data reduction, data presentation, and conclusion: drawing or verifying [9].

\section{RESULT}

\section{The implementation of Blended Learning in Listening Class}

\section{Preparation}

Based on the observation, the researcher found that before teaching the lecturer arranged the course objective and the learning activities. It is also supported by the laboratory classroom, the audio-visual media, computer, and virtual class. The resources needed to support the virtual class are free WIFI access and web sites for students like Google drive/Google Docs and Edmudo.

\section{Arrangement and Development}

The lecturer set of the class activity with 75 per cent was delivered online and 25 per cent face-to-face. In the teaching and learning process, the lecturer used syllabus, materials, handbook, and book chapters. Furthermore, the lecturer assessed students at virtual class. The lecturer maintained control of the class through the participation in the activity when they took the material from Google Docs and Edmodo virtual class, direct and indirect. By virtual class, the lecturer can monitor the students' progress directly. For example, by using online assignment submission students' work was automatically date and time stamped. Virtual classroom or Edmodo can also be used for group discussion between student-student, and student-lecturer collaboratively.

The design of the blended course can be drawn in the model as follows.

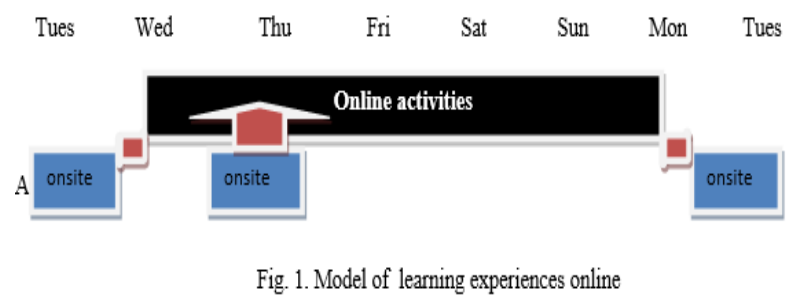

This model shows that he teacher designed a blended course once at the beginning, and once just before the end of the semester.

Implementation

Implementation is the core activity in the process of blended learning; the lecturer arranged the class that the students would be ready for blended learning. In this case the lecturer provided ongoing guidance for any students' activity. The lecturer involved in the online activities such as tutors (for example, discussed and demonstrated how the content might be used in real life, gave direct feedback during an activity) and the lecturer monitored students' involment.

Discussion and evaluation

The students' participation in the discussion and the learning material always been reviewed in the end of the meeting. In this case during the teaching-learning process, the lecturer gave feedback to the students about their presentation as the evaluation. Learning material must also be reviewed by the lecturer in order to get an appropriate material for the students.

\section{Students' Indepedence and Collaboration in Listening class}

The teacher arranged the blended activity onsite and online learning. In the activities students were practiced to work and to formulate an answer to an open-ended task, they talk and work together. When students exchange ideas and insights, they work through misunderstandings, absorb content more effectively, and help each other achieve true understanding. In the online learning also provides students to have independent learning. The concept of blended learning as the combination of face to face and online learning (independently and collaboratively) done by the lecturer in the classroom can be drawn as follows.

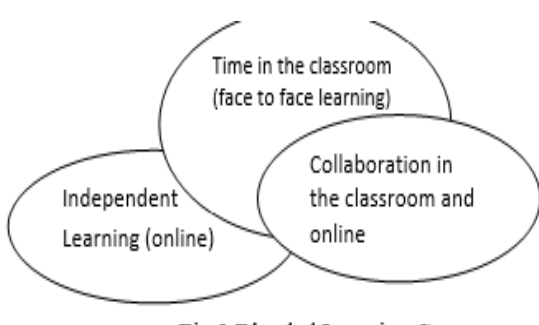

Fig. 2 Blended Learning Concept 


\section{The Student's Response on The Implementation of Blended Learning \\ Learners nowadays expect technology to be} integrated into their language classes. It can be seen from result of the questionnaire that among the 28 students, 26 ( $92.85 \%$ ) of them had been familiar with Google App and Edmudo and they knew about it. The interaction between students and teacher used virtual learning for online activities. Meanwhile based on the observation the teacher implemented the lesson plan in teaching and she sometimes used Google Docs for integrated activity. The teacher prepared suitable activities in groups' discussion using Google Docs and Edmudo to make students active and creative in class eventhough the access of internet in the school did not run well and it sometimes disturbed the learning process. Otherwise, according to the students that the virtual learning activities not only help them identify their mistakes and weaknesses but also solve their problem directly. The percentage of students' response and feeling to this activity are different, 22 students $(78.57 \%)$ say strongly agree with the virtual learning activity, 6 students $(21,43 \%)$ said agree, and no student says strongly disagree with virtual learning activities. Meanwhile the students who are very satisfied are 12 students $(42.86 \%)$, satisfied are 5 students $(57.14 \%)$ and. No student is very dissatisfied with this.

\section{Discussion}

Internet is very essential tool to create an interactive media. Twenty-first century teacher education must place greater emphasis on instructional design, team-building, facilitating learning and new ways to foster creativity and innovation [12]. ICTs must be integrated into teacher education programmes and become commonplace as a tool used throughout teaching careers [10]. However, that nowadays using internet is appropriate to create integrated activities that can expose the skill [11].

In some contexts, teachers are expected to offer blended learning options since blended learning not only fits into the modern, connected lifesyle, but can also provide specific benefits to students, teachers, and administration namely a) increassed access and convenience, b) improved learning, c) decreased cost [16]. Meanwhile Blended learning is to provide additional channels for interaction and opportunities for collaboration [13], [15].

Google Docs and Edmodo are as share resources and web-based collaborative system means of cooperation between the students or group of students with other subject in doing their works and media interactive learning. The teachers together with the students can each edit, review and correct one another in doing their works online and exchange ideas among fellow students and teachers and this is one of the examples that can build and develop students' creativity, critical reading, critical thinking, and also problem solving.

Anyway, students expect technology to be used in classroom as they completely adopted it in their lives [5]. Nowadays students depend on the internet and feel confortable using technology as a medium to learn.

\section{CONCLUSION}

Based on the result of the reseach it can be concluded that the lecturer designed and developed the activities of blended learning namely a) learners' independent work with Online software Google Docs and Edmudo, b) Face-to-face English as a foreign language (EFL) classes led by lecturer as a tutor c) Online monitoring carried out by the lecturer, and d) Weekly discussion and evaluation [2].

In the process of applying blended approach, the lecturer follows each step of blended learning such as prepraring, designing, implementing and reviewing. Preparation is the first step of blended learning process; the lecturer has to understand the students' classrooms' situation. In this case, the lecturer prepared the material, media for recording, and virtual classroom. In the implementation, the lecturer guided the students to join in the activities. In the review, the lecturer has two evaluations for the students (students' performance and learning material). All of them were used to improve the students' activity collaboratively and independently.

Based on the questionnaire given to the students that the use of blended approach in the activity of onsite and online learning give positive response. Firstly, it indicates that the students enjoy the listening activity. Secondly, most of the students agree with this learning method and they believe that it can improve their cooperation and independent learning. Furthermore, online learning may be used to improve their listening skill other than face to face learning in the classroom. In addition, most of the students agree that blended learning is a good teaching method applied in listening class.

\section{REFERENCES}

[1] Ary et al Ary, Donald, et als., "Introduction to Research in Education" Canada: Wadsworth Cengange learning,2010.

[2] Banados, E "A blended-learning pedagogical model for teaching and learning EFL successfully through an online interactive multimedia environment". CALICO Journal 23/3: 533-550., (2006).

[3] Brian Tomlinson and Claire Whittaker," blended learning in English language teaching: course design and implementation”, 2013.

[4] Ceylan and Kesici, "Effect of Blended Learning to Academic Achievement

https://www.researchgate.net/publication/31368322 5, 2017.

[5] Gonzales-Vera,P.2016. "The e-generation: The Use of Technology for Foreign Language Learning, in A.Pareja-Lora, C.Calle-Martinez, \&P.RodriguezArancon (Eds), New Prespective on Teaching and Working with Languages in the Digital Era", Dublin: Research-publishing.net,pp.51-61.

[6] Graham, C.R. "Blended Learning Systems: Definition, Current Trends, and Future Directions”. In Curtis J. Bonk and Charles R. 
Graham (eds.). The Handbook of Blended Learning: Global Perspectives, Local Designs. San Francisco, CA: Pfeiffer, 3-21. 2006.

[7] Isti'anah, Arina (2017) IJEE (Indonesian Journal of English Education)| Vol. 4 | no.1 " The Effect of Blended Learning to the Students'achievement in Grammar Class", 2017.

[8] Kintu et al. "Blended learning effectiveness: the relationship between student characteristics, design features and outcomes" International Journal of Educational Technology in Higher Education 14:7 DOI 10.1186/s41239-017-0043-4,2017.

[9] Miles and Huberman, "Qualitative Data Analysis": A Methods Sourcebook. U.K: SAGE Publications, 2013.

[10] Ó Grádaigh, 2014). Ó Grádaigh, S. 2014. "School in a Box" - Burkina Faso (Interviews: 20 February 2014 and 20 June 2014). National University of Ireland Galway, Galway, Ireland. http://vimeo.com/87853453 (Accessed 21 March 2014).
[11] (Poore, 2013). Poore, M. (2013). "Using social media in the classroom a best practice guide" (1st ed.). U.K.: SAGA Publication

[12] Redecker, C.et.al.. "The Future of Learning: Preparing for Change". Luxembourg, Publications Office of the European Union. http://ftp.jrc.es/EURdoc/JRC66836.pdf (Accessed 5 April 2014).

[13] Richardson, W "Blogs, Wikis, Podcasts and Other Powerful Web Tools for theClassroom". Thousand Oaks, Calif: Corwin Press, 2010.

[14] Sharma, P (2007) "Try a blend that creates a new class of learning. Guardian Weekly (16 February 2007).

[15] Solomon, G and Schrum, L "How 2, Web 2: How to for Educators". Eugene, OR: International Society for Technology in Education, 2010.

[16] Stein, Jared, and Graham, Charles R ,'Esentials for Blended Learning A Standards-Based Guide" New York: Taylor \& Francis Group, 2014. 